\section{Purple urine bag syndrome}

\section{Yoeli Antonio Duarte-Arzuaga* and Ramsey González- Rodríguez}

Urology Service, General Calixto García Clinical Surgical University Hospital, Avenida Universidad y J. Vedado. CP. 10400, Havana, Cuba
Received: 07 May, 2020

Accepted: 15 May, 2020

Published: 16 May, 2020

*Corresponding author: YA Duarte Arzuaga, Urology Service, General Calixto García Clinical Surgical University Hospital, Avenida Universidad y J. Vedado. CP. 10400, Havana, Cuba,

E-mail: duartearzuaga@gmail.com

Keywords: Infection; Urinary catheterization; Escherichia coli; Klebsiella pneumoniae

https://www.peertechz.com

\title{
Abstract
}

Purple Urine Bag Syndrome (PUBS) is an unusual occurrence characterized by the purple coloration of the urine. It is observed in bedridden patients with multiple comorbidities, urinary catheters and subjacent urinary infections by germs including Escherichia coli and Morganella morganii. It is caused by the action of sulfatase and phosphatase-producing bacteria which produce compounds that cross-react with chemicals in urine collection bags, rendering the purple coloration. The objective of the article is to disseminate knowledge about PUBS, which is rare and alarming for the patient and their relatives. We present a case of an 87 -year-old patient, bedridden, with recurrent urinary tract infection due to $E$. coli and Klebsiella pneumoniae, and prolonged urethral catheterization who presented purple urine during admission. The specific antibiotic treatment together with the change of the urinary catheter and the bag managed to rinse the urine.

\section{Introduction}

The syndrome of the purple urine bag is a rare condition, which causes shock and concern to patients, family members and doctors of any specialty. It was first described in 1978 by Barlow and Dickinson [1], in a patient with prolonged urethral catheterization.

It is characterized by the intense purple coloration of the urine and is observed in elderly patients with multiple diseases, but mainly seen in those patients who present two fundamental elements: prolonged urethral catheterization and concomitant urinary infection caused by bacteria producing sulfatase enzymes and phosphatases capable of generating chemical reaction between the urine and the plastic material of the collection bag, which results in red, blue, or purple coloration in the urine. Among these bacteria we can mention Proteus mirabilis, Escherichia coli, Morganella morganii and other less frequent such as Klebsiella pneumoniae, Providencia stuartii, Providencia rettgeri, Enterococcus spp, Serratia marcenescens and Pseudomonas aeruginosa, but also some fungi such as Candida albicans [2].

Because of the uncommon nature of this syndrome and the distress it causes in the patient and the health personnel, the case of a patient who showed purple urine is presented.

\section{Case presentation}

87-year-old female patient, bedridden, with personal pathological antecedents of arterial hypertension, pneumonia to recurrence, recurrent Urinary Tract Infection (UTI) caused by $P$. mirabilis and Escherichia coli, according to urine culture results, as well as urethral catheterization for 8 months prior to consultation in the Internal Medicine emergency service of the Academic Hospital "General Calixto Garcia" of Havana, Cuba for change of coloration and increase in volume of the right lower extremity.

Upon physical examination, hypercolored mucous membranes were observed, decreased vesicular murmur with crackles in both pulmonary fields, blood pressure $90 / 60 \mathrm{~mm} /$ $\mathrm{Hg}$ and increased respiratory rate $(21 \times$ minute $)$ and heart rate $(98 \times \min )$.

Ischemic lesion and edema, which covered the right lower limb, were found in the extremities. The patient was stuporous, disoriented in time and space and Glasgow scale of 8 points.

The figures for haemoglobin and haematocrit were low (88 $\mathrm{g} / \mathrm{L}$ and 0.29 , respectively) and the chest radiograph showed bronchopneumonia. The abdominal ultrasound showed no alterations. The patient was diagnosed and admitted to the hospital for treatment of anemia and bronchopneumonia. 
During her treatment, the collection bag of purple colored urine draws attention (Figure 1). In view of this phenomenon and uncertainty regarding treatment, an evaluation is requested by the Urology service.

The results rule out foods or medications that could explain the discoloration of the urine, so the discoloration is assumed to be occurring inside the urine bag.

A urine culture was performed and reported growth of $E$. coli and K. pneumoniae. A blood culture was also performed but showed no results. The urethral catheter and the urine collection bag were changed, empirical treatment was started with $200 \mathrm{mg}$ intravenous ciprofloxacin every 12 hours. These therapeutic measures eradicated the bacterial pathogens and clarified the urine.

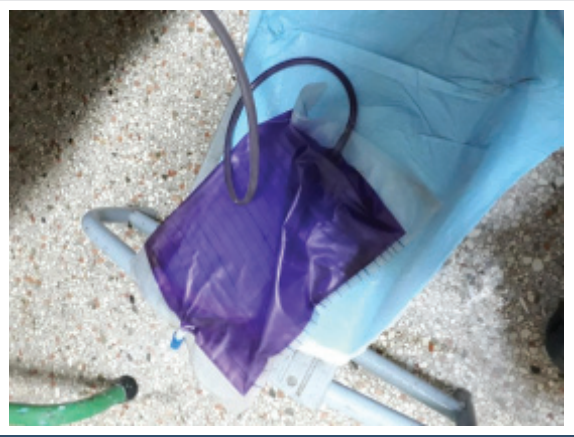

Figure 1: Purple coloration of the collector bag.c

\section{Discussion}

PUBS is a peculiar phenomenon whose mechanism of production is not known with certainty to the present; however, some authors have suggested that a series of biochemical processes involving urine, plastic and certain enzymes of some bacteria producing sulfatases and phosphatases are involved in their occurrence $[3,4]$.

Risk factors are advanced age, female gender, chronic coagulation and permanent catheterization of the urinary tract, as well as dementia, presence of alkaline urine and recurrent UTI. It is also frequent in institutionalized patients $[5,6]$.

It is stated that its genesis can be related to a diet rich in amino acids, mainly tryptophan, which due to the metabolism of bacteria present in the small intestine is deaminated to indole. There it is absorbed and transported to the liver where the indole is conjugated to indoxyl sulphate, that is excreted in the urine and by the action of the bacterial enzymes (sulfatases/ phosphatases) metabolized to indoxyl, which oxidizes it producing indigo (blue coloration) and idirubin (Red color) These substances when combined, and in presence of alkaline urine, react with the plastic material of the bag and bladder catheter manufactured with polyvinyl chloride forming a purple, red coating layer, or a mixture of both $[7,8]$.

Differential diagnoses include the consumption of blackberries, beans, beets and medications such as amitriptyline, indomethacin, triamterene, flutamide, phenol, propofol, doxirubicin and mitoxantrone [9].

\section{Conclusions}

PUBS diagnosis alerts the presence of a UTI, and is usually unquestionable after a thorough anaesthesis and adequate physical examination. It does not require sophisticated complementary studies, but nevertheless it is important to know how to identify it to avoid misdiagnosis and exaggerated treatment. It disappears by treating the UTI according to the result of the urine culture and by changing the urinary catheter and the collection bag.

\section{References}

1. Aubert CJ, Alvarado Lavado FJ, Sánchez Calso A, González González J (2016) Purple urine in the bag. Medicina de Familia. Semergen 42: 25-26. Link: https://bit.ly/2LrE92L

2. Peng TC, Wang CC, Chan JY, Huang SM, Kao TW, et al. (2014) Analysis of risk factors in elderly patients with purple urine bag syndrome: a retrospective analysis in a medical center in northern Taiwan. J Med Sci 34. Link: https://bit.ly/2T7VbXK

3. Zanetti M, Ku V, Ruíz J, González E (2012) Síndrome de la bolsa de orina púrpura: Presentación de un caso. Cuad med forense. 18: 7. Link: https://bit.ly/2T4ul2D

4. Hadano Y, Shimizu T, Takada S, Inoue T, Sorano S (2012) An update on purple urine bag syndrome. Int J Gen Med 5: 707-710. Link: https://bit.ly/2LtE9iF

5. Mastrapasqua S, Rodríguez Somoza F, Martínez MC (2018) Síndrome de la bolsa de orina púrpura. Un caso. Rev Nefrol Dial Traspl 38. Link: https://bit.ly/3fJHXKu

6. Faridi MS, Rahman MJ, Mibang N, Shantajit N, Somarendra K (2018) Purple urine bag syndrome- an alarming situation. J Clin Diagn Res 10: PD05-PD06. Link: https://bit.ly/2y2P6Vd

7. Gamboaa JM, Barbab VN (2017) Síndrome de la orina púrpura. Rev Clin Med Fam 10: 4. Link: https://bit.ly/2T8gJ6z

8. Iglesias Barreira R, Albiñana Péreza MS, Rodríguez Penína I, Bilbao Salcedob J (2013) Síndrome de la bolsa de orina púrpura en dos pacientes institucionalizados. Rev Esp Geriatr Gerontol 48: 15. Link: https://bit.ly/2WSiE0g

9. Golzarri MF, Hernaiz-Leonardo JC, Díaz-González A, Velázquez-Acosta C Vilar-Compte D (2017) Síndrome de la bolsa de orina morada (SBOM): una manifestación infrecuente de infección de vías urinarias (IVU). Gac Med 153 6. Link: https://bit.ly/2zHWnKt 